\title{
Erratum to: The role of pectic composition of cell walls in the determination of the new shape-functional design in galls of Baccharis reticularia (Asteraceae)
}

\author{
Anete Teixeira Formiga • Denis Coelho de Oliveira • \\ Bruno Garcia Ferreira • Thiago Alves Magalhães • \\ Ariane Chagas de Castro • G. Wilson Fernandes • \\ Rosy Mary dos Santos Isaias
}

Published online: 18 January 2013

(C) Springer-Verlag Wien 2013

\section{Erratum to: Protoplasma}

\section{DOI 10.1007/s00709-012-0473-8}

The black target at the bottom of figure 3 prevents the identification of the corresponding letters for each photo and scale bars. The figures are $\mathrm{J}, \mathrm{K}$ and $\mathrm{L}$ from left to right, the scale bars for each photograph correspond to $(\mathrm{J}) 1 \mathrm{~cm}$, $23(\mathrm{~K}) 0.7 \mathrm{~cm}$, and (L) $1 \mathrm{~cm}$.

The online version of the original article can be found at http://dx.doi.org/ 10.1007/s00709-012-0473-8.

A. T. Formiga • B. G. Ferreira • T. A. Magalhães · A. C. Castro •

G. W. Fernandes $\cdot$ R. M. S. Isaias $(\bowtie)$

Instituto de Ciências Biológicas,

Universidade Federal de Minas Gerais - UFMG-ICB,

Belo Horizonte, MG CEP: 31270-901, Brasil

e-mail: rosy@icb.ufmg.br

D. C. Oliveira

Instituto de Biologia, Universidade Federal

de Uberlândia - UFU-INBIO, Uberlândia, MG, Brasil

e-mail: denisoliveira@inbio.ufu.br 